\title{
Managing University Congregation Election in Nigeria for Better Result
}

\author{
Chika Josephine Ifedili ${ }^{1} \&$ Oghomwen Agbonaye ${ }^{1}$ \\ ${ }^{1}$ Faculty of Education, University Of Benin, Edo State, Nigeria \\ Correspondence: Chika Josephine Ifedili, Faculty of Education, University of Benin, P.O. Box 10073, Ugbowo, \\ Benin City, Edo State, Nigeria. E-mail: theifedilis@yahoo.com
}

Received: November 25, 2011 Accepted: March 1, 2012 Online Published: July 1, 2012

doi:10.5539/ach.v4n2p127

URL: http://dx.doi.org/10.5539/ach.v4n2p127

\begin{abstract}
The study investigated the conduct of university's congregation election following the general complaints by university staff of poor organization and conduct. The population consisted of all principal officers and all graduates employed by the various universities in the three geo-political zones of Nigerian federation: North-Central, Southeast, and Southwest. From these zones, a sample of two federal and two state universities were selected by stratified random sampling method for the study. A stratified random sampling method was used to select 200 (100 academic and 100 non-academic) staff from each of federal government universities while 100 (50 academic and 50 non-academic) staff was selected from state universities. A total sample of 900 academic staff (450 males and 450 females) and 900 administrative staff (450males and 450 females) participated in the study. The data of the study were collected using questionnaire. The questionnaire was titled Management of Congregation Election Inventory (MCEI). It was made up of two parts - Part A was demographic while Part B contained 12 questions bothering on organization of previous elections, management and outcome of previous election results. The validity of the questionnaire was made by the experts in educational administration and planning and also in political Science. The reliability of the instrument was tested using a Split-Half Method. The Correlation Coefficient was corrected by the use of Spearman Brown Formula. The Pearson Product Moment Correlation was .75 and final Spearman Brown Formula yielded 0.82. The major finding was that election was poorly organized and conducted, Based on the findings, the major recommendation was a surgical change in the organization and conduct of congregation election.
\end{abstract}

Keywords: managing, congregation, election, Nigerian, universities

\section{Introduction}

People decide their rulers and assign persons to rulership position. Since there is voluntary participation in the choice of leaders, legitimacy is bequeathed or invested. According to Peretomade (2008), election is seen as a process of decision making of thought and deliberation that results in individuals or members of an organization both opportunities and problems and providing solution to problems. It involves voting to choose from candidates or contestants that will be capable of actualizing the purpose of the organization. Fiorina (2001) saw election as voting behavior which is purposeful. He believed that the voters choose their candidates based on most personal benefit which is the height of rationality. Guy (2006) saw election as the preferred means for solving or mediating competition. In fact, if there is no competition, there will be no election.

Universities in Nigeria are formal organizations and consequently use election to fill their various competitive vacant committee positions. In the universities, the congregation election is legally participated by all principal officers and all graduates employed by the various universities.

Ikelegbe (2004) asserted that the success and performance of election show how peaceful and effective democratic transitional process is and reflects the level of political development and systematic stability. In the same vein, Kunle (2007) opined that the creditability and general acceptance of any election outcome and legitimacy of the elected persons are a function of the transparency, freeness and fairness of the electoral process. Aliyu (2009) stressed that the failures to conduct fair election are mostly practiced in Africa, Middle East and 
some Asian countries while in America and some western countries, high standard is maintained and in accordance with due process.

The present Congregation Election in most of the Nigerian universities is quite undesirable. There have been complaints about rigging, double voting, non-university workers voting, undue campaign, poor timing and delays in the organization of the election, wrong candidates running for the posts they are not qualified to run, poor time management, poor accreditation, unnecessarily waste of resources in massive campaigning etc. The whole excise looks so chaotic and stressful for the participants. The days for elections sometimes coincide with other important activities in the universities. This creates problem of full participation. Power failures have been recorded and sometimes, the votes are counted with lantern. There is need to elect right candidates for effective and efficient performance of various responsibilities they are supposed to undertake. A university is full of knowledgeable and highly experienced individuals. It is supposed to be the role model to other organizations in the organization and conduct of election. The public is always concerned with what goes on in the universities. This is because a university is seen as a pace setter.

At Cambridge University according to Wall (2011), there is as an ideal model for congregation election. The officers to be elected are usually screened, nominated and their curriculum Vitae made public before the election. This is not the case with many Nigerian universities. In most cases candidates' names are not publicized except on the voting day. The Oxford University according to Webmaster (2011), has similar procedure as Cambridge University except that the balloting papers are sent out and the final day for submission stated. The ballot papers which are not received before the deadline are not counted. The election is often done in a highly civilized and legal way that the result is never contested.

\subsection{Statement of the Problem}

The university like any formal organization needs the best personnel to manage its various vacant positions. The present poor organization and conduct of election create room for rigging, poor timing and poor time management, voting wrong persons into positions etc. there is a feeling that the election is stressful and could be better if the organizers make solid plan for the organization and conduct of the election and implement it judiciously. The complaints about congregation election irregularities seem to be more with the academic staff than the non-academic staff. There is need to find out scientifically if the complaints are true and if the non-academics are comfortable with the present method of conducting congregation election.

\subsection{Research Questions}

Based on the above stated problems, the following questions are raised to guide the research study:

1. Is the present method of conducting congregation election adequate for the selection of best candidates?

2. Are all the candidates for election qualified?

3. Are only accredited eligible voters allowed to vote?

4. Is time properly managed during the election?

5. Is the timing of the election conducive?

6. Are materials adequate and well arranged for the smooth running of the election?

7. Are the congregation members happy with the overall conduct of election?

\subsection{Hypotheses}

The following null hypotheses are raised from the research questions above:

1. There will be no significant difference in the responses of male and female congregation members as to the adequacy of present method of conducting congregation election in selecting the best candidates.

2. There will be no significant difference in the responses of academic and non-academic congregation members as to the adequacy of present congregation election in selecting the best candidates

3. There will be no significant difference in the responses of academic and non-academic voters as to whether the time management was conducive for election.

\subsection{Significance of the Study}

This study will benefit government by knowing that her policies which are being implemented by various universities are being carried out by qualified elected personnel. The university administration will be happy to work with hard working and qualified elected individuals who can move the university forward. The university community will be glad to know that fair and free election is possible and time can be better managed. Also, all 
stresses usually encountered will be the thing of the past. Most importantly, peace which is highly desired in every organization will reign.

\section{Methodology}

The research design used was survey. The population consisted of all principal officers and all graduates employed by the various universities in the three geo-political zones of Nigerian federation: North-Central, Southeast, and Southwest. From these zones, a sample of two federal and two state universities were selected by stratified random sampling method for the study. A stratified random sampling method was used to select 200 (100 academic and 100 non-academic) staff from each of federal government universities while 100 (50 academic and 50 non-academic) staff was selected from state universities. A total sample of 900 academic staff (450 males and 450 females) and 900 administrative staff (450males and 450 females) participated in the study.

The data of the study were collected using questionnaire and oral interview. The questionnaire was titled Management of Congregation Election Inventory (MCEI). It was made up of two parts - Part A was demographic while Part B contained 12 questions bothering on organization of previous elections, management and outcome of previous results. The validity of the questionnaire was made by experts in Educational Administration and Planning and Political Science. The reliability of the instrument was tested using a Split-Half Method. The Correlation Coefficient was corrected by the use of Spearman Brown Formula. The Pearson Product Moment Correlation was .75 and final Spearman Brown Formula yielded 0.82. The statistics used for data analysis were Z-test and percentage. The scoring was based on $0-1.00$ as very poor; $1.01-1.99$ as poor; $2.00-2.50$ as average, $2.51-3.50$ as good and $3.51-4.00$ as excellent.

\section{Results}

Answers to Research Questions are on Table 1.

Table 1. Answers to research questions

\begin{tabular}{lccc}
\hline & YES & NO \\
\hline $\begin{array}{l}\text { 1. Is the present method of conducting Congregation adequate for the selection of best } \\
\text { candidates? }\end{array}$ & $13 \%$ & $87 \%$ & $100 \%$ \\
2. Are all the candidates for election qualified? & $63 \%$ & $37 \%$ & $100 \%$ \\
3. Are only accredited eligible voters allowed to vote? & $06 \%$ & $94 \%$ & $100 \%$ \\
4. Is time properly managed during the election? & $15 \%$ & $85 \%$ & $100 \%$ \\
5. Is the timing of the elective conducive? & $11 \%$ & $89 \%$ & $100 \%$ \\
6. Are the materials adequate and well arranged for smooth running of election? & $12 \%$ & $88 \%$ & $100 \%$ \\
7. Are congregation members happy the overall conduct of election? & $7 \%$ & $93 \%$ & $100 \%$ \\
\hline
\end{tabular}

\subsection{Testing Hypotheses}

H01 The first null hypothesis which states that there will be no significant difference in the responses of male and female congregation members as to the adequacy of present method of conducting congregation election in selecting the best candidates was tested and the result is as on Table 2 .

Table 2. Test of significant difference on the adequacy of present method in conducting congregation election based on sex of members

\begin{tabular}{lcccc}
\hline Statistics & Males & Females & Calculated Z-Test & Table Value \\
\hline Number & 900 & 900 & & \\
Mean & 1.92 & 1.95 & 1.66 & 1.96 \\
SD & .35 & .40 & & \\
\hline
\end{tabular}

From Table 2, the calculated Z-Value is 1.66 at 0.05 - Confidence Level. The null hypothesis that there will be no significant difference in the responses of male and female congregation members as to the adequacy of 
present method of congregation election in selecting the best candidates is therefore accepted. Both the academic and non-academics agreed that the present method of conducting election was poor. Eight-seven percent of the respondents agreed that the present method was deficient as opposed to $13 \%$ that responded positively.

HO2 The second null hypothesis that states that there will be no significant difference, in the responses of academic and non-academic congregation members, as to the adequacy of present congregation election in selecting the best candidates, was analyzed with the data collected from the questionnaire and the result is on Table 3 .

Table 3. Test of significant difference between the responses of academic and non-academic staff on the adequacy of the present method of conducting congregation election

\begin{tabular}{lcccc}
\hline Statistics & Academics & Non-Academics & Calculated Z-Test & Table Value \\
\hline Number & 900 & 900 & & \\
Mean & 1.95 & 1.98 & 1.58 & 1.96 \\
SD & 0.38 & 0.41 & & \\
\hline
\end{tabular}

From Table 3, the calculated Z-Value at 0.05 -Confidence Level is 1.58 while the Table Value is 1.96 , the null hypothesis that states that there will be no significant difference, in the responses of academic and non-academic congregation members, as to the adequacy of present congregation election in selecting the best candidates is therefore accepted. Both the academic and non-academics agreed that the method was poor. Ninety-four percent of the academics as opposed to $89 \%$ of the non-academics responded that the method of election was poor. Only $06 \%$ of the academics as opposed to $11 \%$ of non-academic agreed that the method of election was fair. No one responded that the election method was neither good nor excellent.

HO3 The third null hypothesis that states that there will be no significant difference in the responses of academic and non-academic staff as to whether the time management was conducive for election was analyzed from the collected data and the result is on Table 4.

Table 4. Test of significant difference between the responses of academic and non-academic on the time management of congregation election

\begin{tabular}{lcccc}
\hline Statistics & Academics & Non-Academics & Calculated Z-Test & Table Value \\
\hline Number & 900 & 900 & & \\
Mean & 1.96 & 2.01 & 3,13 & \\
SD & .36 & .31 & & \\
\hline
\end{tabular}

From Table 4, the calculated Z-Value at 0.05 -Confidence Level is 3.13 while the Table Value is 1.96 . The null hypothesis that stated that there will be no significant difference in the responses of academic and non-academic staff, as to whether the time management was conducive for election was therefore rejected. There was a significant difference. The academics responded that the time management was poor while the non-academics agreed that it was of average. None of the participants rated the conduct of election as good or excellent.

\subsection{Discussion}

From the analysis of data collected, $87 \%$ of the respondents agreed that the method of the conduct of university's congregation election was poor. This is the first signal that there is need for reform. Although $63 \%$ of participants agreed that the candidates for election were qualified, $37 \%$ felt they were not. The university constitution stated the qualification the candidate must have before applying for the post. This was always checked before nomination is made. This means that there were some candidates who were not qualified. When some participants were randomly interviewed, they opined that the qualification should not be based only on paper qualification. They asserted that some candidates had no integrity and some psychologically were not qualified.

Ninety-four percent of the respondents agreed that there was an accreditation, but not only those accredited, were allowed to vote. There used to be three hours accreditation but those who came after accreditation were also 
allowed to vote. There was no restriction to vote as long as one is a congregation member. This is at variance with the law guiding congregation election. Also, poor time management and poor timing were indicated by $85 \%$ of the respondents. Most of the elections were scheduled on Fridays in the past. This made attendance poor because of some religious, social and political commitments. According to some participants who were randomly interviewed, most of the elections in the past started at noon after two or three hours of accreditation but stretched towards midnight. In most cases there was power failure and no standby generators. Lanterns were used and this created loop holes for rigging. There were some unethical campaign practices which all the respondents would like to stop. The major one is the expensive cooking for the voters and giving them drinks before election.

It was also observed that material for election was inadequate and poorly organized.

\section{Conclusion}

The success of any election is based on peaceful and effective transitional process. The past university congregation elections from the above have not been peaceful. It is marred with poor organization and poor conduct. Time which is an importance factor is poorly managed and the elections were poorly timed. This has made participation to be low. There was no restriction on non-accredited members to vote. There was no order. None congregation members vote without being challenged. The problems encountered should be tackled so that efficient and effective congregation election could be realized. Nigeria has not reached the stage of distributing ballot papers and returning them on the specific date. Only what can be done at the mean time is to make some changes in the present election method so as to make it as fair and free as possible. Transparency and meritocracy can never be sacrificed. There should be trust when election is properly conducted. The university should set a pace to show the society at large what good conduct of election means.

\section{Recommendations}

In order to make university congregation election more desirable, the following are recommended for the surgical change:

- There should be conferences, seminars and workshop to create public awareness on the importance of properly organized and conducted election.

- The timing of the elections should not be on Fridays but midweek in order to ensure full participation.

- All materials needed for election should be adequate and properly prepared. They should be numbered, stamped and duly signed. All vacant posts and the contestants should be indicated. The voter will just thick the choice and drop the form in the highly secured ballot boxes.

- Candidates for election should be screened.

- There must be accreditation of all members who want to vote.

- Only those accredited should be given election forms with the form number written against the voter's name.

- At the end of the accreditation, the forms are picked and the contestants' votes counted. This should be done at the maximum of two hours.

- The winners should be announced immediately. There should not be any sort of delays.

- Any unethical campaigning is unacceptable. Campaigning should be limited to promotion of manifestos.

- High powered security should be put in place to ensure full compliance.

- There is need for a committee to be set up to screen the prospective contestant. This should be done before a candidate is allowed to contest.

- No tout should be allowed in the vicinity during the election.

\section{References}

Aliyu, A. (2009). Concept of democratic election under international law. Research Journal of International Studies, 10.

Fiorina, M. (2001). Retrospective voting in American national elections. New Heaven: Yale University Press.

Guy, S. (2006). Free and Fair election (pp. 113-117). Inter Parliamentary Union, Grand Saconnax, Geneva, Switzerland. 
Ikelegbe, A. (2004). Issues and problems of Nigerian politics. Imprint Services, Benin City.

Kunle, A. (2007). Election administration in Nigeria and the challenges of 2007 election. The Social Science, 2, $142-151$.

Peretomade, U. F. (2008). Educational administration: applied concepts and theoretical perspectives for students and practitioners. Ikeja: Joja Internationals and Publishers Ltd.

Wall, A. (2011). Forms of electing the officers in the university. 